$\stackrel{\circ}{\text { III }}$

\title{
NARODZINY NOWEJ HUMANISTYKI Z DUCHA GENDER
}

ABSTRACT. Grzegorz Dziamski, Narodziny nowej humanistyki z ducha gender [The Birth of the New Human Sciences from the Spirit of Gender], edited by Z. Drozdowicz, S. Sztajer, "Człowiek i Społeczeństwo", vol. XXXIX, Poznań 2015, pp. 49-56. Adam Mickiewicz University Press. ISBN 978-83-2322953-7, ISSN 0239-3271.

If we accept the distinction between sex and gender, introduced by the Second Wave of Feminism, and if we agree that gender does not have to be limited to two sexes, we will enter the terrain of the queer, the world of labile, liquid sexuality where the borders between men and women get blurred and the space opens for creating various human hybrids. In Poland, the middle of 1990 saw the launch of the women's studies, gay and lesbian studies, gender studies, queer, LGBT, opening new domains and new methods of human studies. We can call them post-feminist and cultural studies because they stem from the feminist distinction between sex and gender and are focused on gender, i.e. on cultural rather than biological determinants of human beings. The new human sciences will have to face such new narratives of human beings, rethink the concept of objectivity (science) and commitment, learn to live in pluralistic world of many theories and more precisely many discourses, and to learn to cooperate with various groups to present their point of view. But first of all, the new human sciences will have to replace the idea of unity by idea of difference. Once we were looking for unity, now we are looking for difference.

Grzegorz Dziamski, Uniwersytet im. Adama Mickiewicza w Poznaniu, Instytut Kulturoznawstwa, ul. Szamarzewskiego 89, 60-568 Poznań, Poland

Kiedy feministki wprowadziły rozróżnienie na sex i gender, płeć biologiczną i płeć kulturową, wszystkim wydawało się to oczywiste i niewymagające specjalnego uzasadnienia. Rozróżnienie to zaproponował neofeminizm 
lat 60., nazywany także feminizmem drugiej fali ${ }^{1}$, który dobrze rozumiał, że prawne zrównanie kobiet z mężczyznami nie wystarczy do zniesienia dyskryminacji kobiet, że potrzebna jest jeszcze zmiana wizerunku kobiety, zmiana kulturowych stereotypów wiązanych z kobiecością. Płeć jest bowiem nie tylko wytworem biologii, ale także, i to w dużym stopniu, kultury. Jeżeli tak, to sensowne staje się pytanie, gdzie przebiega granica między tym, co biologiczne, a tym, co kulturowe, między tym, co konieczne, a tym, co niekonieczne, bo tak można byłoby rozumieć różnicę między biologicznym a kulturowym.

Biologia decyduje o tym, że to kobieta, a nie mężczyzna rodzi dzieci, ale o tym, że kobieta gotuje, pierze, sprząta, opiekuje się dziećmi i starymi, zniedołężniałymi członkami rodziny, w skrajnych przypadkach rezygnuje z zamążpójścia, by opiekować się rodzicami, o tym decyduje już kultura, a nie biologia, i dlatego można to w miarę szybko zmienić. Sytuacja, kiedy kobieta gotuje, pierze, sprząta, a mężczyzna kosi trawę w ogródku, naprawia płot lub składa motocykl w garażu, albo - jeszcze gorzej - czyta gazetę lub ogląda telewizję, nie jest naturalna, lecz kulturowa. Mężczyzna może przecież zacząć gotować, prać i sprzątać, co zresztą coraz częściej się dzieje, dlatego nie mówimy już dzisiaj o naturalnym, a raczej o tradycyjnym podziale ról i obowiązków. Jest to ogromna zmiana, której trudno nie docenić.

A co z sytuacją, zapytajmy, kiedy gotowaniem, praniem i sprzątaniem zajmują się osoby trzecie, specjalnie do tych prac najęte? Nikt nie buduje przecież wielkich domów po to, by zwiększyć liczbę okien do umycia i pokoi do sprzątania. Ujawnia się tu rzadko podnoszony przez feministki problem relacji między kobietami-paniami domu a kobietami najmowanymi do prac domowych, często Polkami w Niemczech, Ukrainkami w Polsce, Kolumbijkami czy Ekwadorkami w Hiszpanii.

Wydawało się, że odróżnienie sex od gender, tego, co biologiczne, od tego, co kulturowe, nie będzie specjalnie trudne, choć pojawią się oczywiście pewne obszary niejasne, liminalne, jakby powiedział Victor Turner, np. macierzyństwo. Tymczasem rzeczywistość okazała się znacznie bar-

${ }^{1}$ Wykorzystuję tu podział Kate Millett z Sexual Politics (1969) na pierwszą rewolucję feministyczną (long revolution 1792-1930), czas kontrrewolucji (1930-1960) oraz drugą rewolucję, czyli neofeminizm (lata 60.). Zob. G. Dziamski, Sztuka feministyczna: od outsidera do innego, w: idem, Sztuka u progu XXI wieku, Wyd. Fundacji Humaniora, Poznań 2002, ss. 73-77. Kazimierz Ślęczka posługuje się podobnym podziałem, wyróżnia bowiem pierwszą falę feminizmu (First Wave Feminism), interludium (1920-1963) oraz drugą falę (Second Wave Feminism). Zob. K. Ślęczka, Feminizm. Ideologie i koncepcje społeczne współczesnego feminizmu, Książnica, Katowice 1999. 
dziej skomplikowana. Każda próba zdefiniowana płci biologicznej odsyła nas bowiem od razu do kultury. Jeżeli kobieta, w sensie biologicznym, jest samicą zdolną do rodzenia, to powstaje pytanie, co z tymi kobietami, które z różnych powodów dzieci nie urodziły? Czy utraciły swoją kobiecość? Przestały być kobietami? A jeżeli przestały być kobietami, to kim się stały? Kim są kobiety, które „przestały być postrzegane jako istoty seksualne”? pyta Gayatri Ch. Spivak². Mężczyznami? Simon de Beauvoir mówi tu, lekko żartobliwie, o „trzeciej płci”3. Trzecia płeć to groźba zawieszona nad tymi, którzy chcą się wyłamać z heteroseksualnej normy, z podziału na kobiety i mężczyzn, to kobiety, które nie chcą być kobietami, i mężczyźni, którzy nie chcą być mężczyznami, to wydzielone pomieszczenie, w którym panuje nieopisany bałagan, aby w reszcie domu można było zaprowadzić porządek.

Simon de Beauvoir pisze, że kobieta, w sensie biologicznym, to „ludzka samica”4 I zaraz dodaje, że określenie „samica” ma w naszej (męskiej? patriarchalnej?) kulturze bardzo złe konotacje, w przeciwieństwie do określenia „samiec”, które kojarzy się z samcem alfa, a więc z przywódcą, liderem, kimś dominującym. Samica natomiast, nawet lwica czy tygrysica, kojarzy się z czymś lubieżnym, podstępnym, dzikim, niecierpliwym, biernym, pokornym, z cechami, które oceniamy negatywnie. Wzorcowego przykładu dostarcza tu opozycja pies - suka; jeżeli pies jest symbolem tego, co cenimy - wierności, to suka jest całkowitym zaprzeczeniem tej cechy ${ }^{5}$.

Oddzielenie płci biologicznej (sex) od płci kulturowej (gender) wydawało się oczywiste. Zdarza nam się przecież słyszeć albo nawet wypowiadać takie zdania: „ona zachowuje się jak mężczyzna”, „ona myśli jak mężczyzna” albo „on ma kobiecą wrażliwość”. Mamy więc pewien obraz męskości i kobiecości ukształtowany przez kulturę, który pozwala nam się tak wyrażać. Płeć kulturowa reinterpretuje płeć biologiczną, ta ostatnia nigdy bowiem nie występuje w postaci czystej, zawsze jest kulturowo przetworzona. W różnych kulturach będą to różne interpretacje, co w rezultacie da różne obrazy kobiet i mężczyzn; inne w kulturze Zachodu, inne w kulturze muzułmańskiej, jeszcze inne w kulturach dalekiego Wschodu, chińskiej czy japońskiej. Interpretacje będą się też zmieniały w zależności od pozycji społecznej kobiety, jej przynależności klasowej, wykształcenia, profesji,

${ }^{2}$ G.Ch. Spivak, Z pieczq̨tkq Kalkuty, tłum. J. Majmurek, w: S. Harasym (red.), Strategie postkolonialne, Wyd. Krytyki Politycznej, Warszawa 2011, s. 108.

${ }^{3}$ S. de Beauvoir, Druga płeć, t. I: Fakty i mity, tłum. G. Mycielska, Wyd. Literackie, Kraków 1972, s. 74.

${ }^{4}$ Ibidem, s. 45.

${ }^{5}$ Ibidem, ss. 46-47. 
zamożności itd. Jaka więc relacja łączy płeć kulturową z płcią biologiczną? Czy płeć kulturowa może jedynie potwierdzać płeć biologiczną, czy może być z nią sprzeczna? Ktoś anatomicznie, fizycznie wygląda jak kobieta, ale czuje się mężczyzną? I sytuacja odwrotna: ktoś ma męskie ciało, ale czuje się kobietą? Można postawić pytanie, czy płcie kulturowe muszą być dwie, jak ma to miejsce w przypadku płci biologicznej? Feministki drugiej fali odwołały się do autorytetu antropologii. Joanna Bator, kiedyś kulturoznawczymi, a dzisiaj znana pisarka, podkreśla, że inspiracją do oddzielenia płci biologicznej od kulturowej były badania antropologiczne, prowadzone głównie przez Margaret Mead ${ }^{6}$. Badania te wykazały, że „podział na dwie płcie biologiczne jest uniwersalny, ale sensy łączone z tym, co kobiece, i tym, co męskie, zależą od kontekstu danej kultury”7. Można więc powiedzieć, że biologia łączy kobiety, a kultura różnicuje.

Jeżeli zgodzimy się z feministkami drugiej fali, że płeć kulturowa nie musi pokrywać się z płcią biologiczną i że płcie kulturowe nie muszą być dwie, tylko może ich być znacznie więcej, to jesteśmy już na terenie queer, w świecie niestabilnej, płynnej płciowości, gdzie zamazują się różnice między kobietami i mężczyznami i otwarte zostają możliwości tworzenia ludzkich hybryd. Jesteśmy w świecie, w którym „mężczyzna oraz męski może równie łatwo odsyłać do ciała żeńskiego, jak i męskiego, a kobieta i kobiecy może oznaczać i ciało męskie, i żeńskie”.

W filmie Davida Cronenberga M. Butterfly (1993) francuski dyplomata Rene Gallimard, grany przez Jeromy’ego Ironsa, zakochuje się w chińskiej śpiewaczce operowej. Kiedy okazuje się, że śpiewaczka nie jest kobietą, lecz mężczyzną (w dodatku szpiegiem, co ma tutaj drugorzędne znaczenie), Gallimard jest w szoku, ale nie przestaje jej/jego kochać. Pytanie: kogo pokochał Gallimard: kobietę czy mężczyznę? I kim jest Gallimard? Mężczyzną hetero- czy homoseksualnym?

„Nie rodzimy się kobietami - stajemy się nimi” - pisze Simon de Beauvoir w Drugiej płci ${ }^{9}$. Jest to prawdopodobnie najsłynniejsze zdanie tej książki, niektórzy chcieliby nawet całą książkę francuskiej pisarki zamknąć

${ }^{6}$ M. Mead, Sex and Temperament in Three Primitive Societies, William Morrow, New York 1935. Polskie wydanie: M. Mead, Płeć i charakter w trzech społecznościach pierwotnych, PIW, Warszawa 1986.

${ }^{7}$ J. Bator, Feminizm, postmodernizm, psychoanaliza. Filozoficzne dylematy feministek drugiej fali, słowo/obraz terytoria, Gdańsk 2001, s. 56.

${ }^{8}$ J. Butler, Uwikłani w płeć, tłum. K. Krasuska, Wyd. Krytyki Politycznej, Warszawa 2008, s. 51.

${ }^{9}$ S. de Beauvoir, Druga płeć, t. II: Kształtowanie się kobiety, sytuacja, usprawiedliwienia i ku wyzwoleniu, tłum. M. Leśniewska, Wyd. Literackie, Kraków 1972, s. 11. 
w tym jednym zdaniu. Tymczasem stwierdzenie to jest banalne, szczególnie w kontekście przyjętej przez Beauvoir filozofii. Nikt nie rodzi się tym, kim jest, tylko się nim staje. Nikt nie rodzi się geniuszem, tylko się nim staje. Nikt nie rodzi się profesorem filozofii, tylko się nim staje itd. Judith Butler poddaje zdanie francuskiej autorki nietrywialnej interpretacji: „Nic w jej przemyśleniach nie wskazuje na to, że ktoś, kto staje się kobietą, koniecznie jest płci żeńskiej”10. Innymi słowy, bez względu na to jak dziwnie by to na pierwszy rzut oka wyglądało, każdy, literalnie każdy może stać się kobietą, ponieważ Butler w miejsce ekspresywnie rozumianej tożsamości proponuje tożsamość performatywną. Wbrew temu, co się powszechnie uważa, kobieta nie jest gotowym podmiotem wyrażającym się w określonych przedstawieniach (reprezentacjach), lecz dokładnie na odwrót - to przedstawienia tworzą kobietę; „,nie istnieje żadna uprzednia wobec nich [aktów performatywnych - G.D.] tożsamość, która mogłaby być owych aktów i atrybutów miarą"11. W ten sposób - jak trafnie zauważa Olga Tokarczuk we wstępie do polskiego wydania książki Judith Butler - znika kobieta, a jej miejsce zajmuje podmiot określający swoją płciową tożsamość w werbalnych i pozawerbalnych aktach performatywnych $^{12}$. Nie ma więc kobiety jako jednego podmiotu, lecz wiele podmiotów, z których każdy ma własne wyobrażenie kobiety, a może własną fantazję na temat kobiety. Można zatem mówić o kobietach bardziej i mniej kobiecych, przywiązujących mniejszą lub większą wagę do kobiecości itd.

Koncepcja Butler może wydawać się z pozoru absurdalna - bycie kobietą ma być wynikiem aktów performatywnych! Ale przecież dobrze wiemy, ile razy każdego dnia musimy siebie i innych przekonywać, że jesteśmy normalni, że wszystko robimy zgodnie z rolą, jaką sobie wybraliśmy i jaką nam przypisano. W rozważaniach Butler znika płeć biologiczna (sex), pozostaje wyłącznie płeć kulturowa (gender), która ma charakter performatywny, a tożsamość płciowa staje się realizacją, ucieleśnieniem naszego fantazmatu na temat płci ${ }^{13}$. Rodzi się tu pytanie, czy teoria rozwijana przez Judith Butler jest jeszcze teorią feministyczną, czy już teorią czegoś innego, np. teorią queer? Queer dosłownie znaczy dziwny, cudaczny, nienormalny, zbzikowany. Przywykliśmy tłumaczyć ten termin na język polski jako „odmieniec”. Czy teoria Butler miała być teorią odmieńców? Próbą ogarnięcia tych wszystkich dziwaków, których Simone de Beauvoir zaliczyła do trzeciej płci i chciała zamknąć w osobnym pomieszczeniu, by nie burzyli heteroseksualnego ładu?

\footnotetext{
${ }^{10}$ J. Butler, Uwikłani w płeć, s. 55.

${ }^{11}$ Ibidem, s. 253.

12 O. Tokarczuk, Kobieta nie istnieje, wstęp do J. Butler, Uwikłani w płeć.

13 J. Butler, Uwikłani w płeć, s. 246.
} 
Joanna Mizielińska zauważa, że do połowy lat 90. XX wieku nie było w Polsce dyskursu na temat płci i seksualności - w 1996 r. powstały pierwsze gender studies na Uniwersytecie Warszawskim. W drugiej połowie lat 90. zaczęliśmy nadrabiać opóźnienie wobec Zachodu i przyswajać sobie rozwinięte tam sposoby myślenia, co sprawiło, że niemal równocześnie pojawiły się w Polsce women’s studies, gay and lesbian studies, gender studies, queer, LGBT ${ }^{14}$, otwierając nowe obszary i nowe metody badań humanistycznych, które można nazwać postfeministycznymi i kulturowymi. Postfeministycznymi, ponieważ ich źródłem jest feministyczne oddzielenie płci kulturowej od płci biologicznej, a kulturowymi, ponieważ koncentrują się na płci kulturowej, czyli na kulturowych, a nie biologicznych determinantach płci, na tym, co różni, a nie na tym, co łączy.

W Polsce możemy dzisiaj obserwować eksplozję dyskursów, które na Zachodzie powstawały przez ostatnie 50-60 lat. Mamy więc ciągle jeszcze atrakcyjny dyskurs feministyczny, walczący z pozostałościami patriarchatu i próbujący przewartościować heteroseksualne normy. W tym dyskursie, jak zauważa Olga Tokarczuk, lesbijki traktowane są często jak nie-kobiety lub też kobiety, które dobrowolnie wyrzekły się swej kobiecości, i dlatego nie uwzględniono ich problemów w deklaracjach programowych Partii Kobiet, która zawiązała się przed wyborami parlamentarnymi w 2011 r. ${ }^{15}$

Mamy dyskurs gejowsko-lesbijski czy też homoseksualny, coraz silniej obecny w sferze publicznej, który próbuje wprowadzić własną binarną opozycję: homo - hetero w miejsce heteroseksualnej opozycji kobieta - mężczyzna. Pod koniec lat 70. Służba Bezpieczeństwa, chcąc skompromitować Jerzego Andrzejewskiego, rozpuszczała plotki, że sędziwy pisarz domaga się legalizacji związków homoseksualnych ${ }^{16}$. Dyskurs homoseksualny próbuje nas przekonać, że bycie homoseksualistą niczym nie różni się od bycia osobą heteroseksualną i dlatego parom czy związkom homoseksualnym powinny przysługiwać takie same prawa co związkom heteroseksualnym. Dyskurs homoseksualny zaczyna dziś sięgać do argumentów sprzecznych z koncepcją płci kulturowej, kiedy mówi o wrodzonej orientacji seksualnej czy o genie homoseksualnym, który sprawia, że zawsze i wszędzie pewien niewielki procent populacji rodzi się homoseksualistami. Zatem wbrew

14 J. Mizielińska, Idee pogubione w czasie - polityka LGBT vs. teoria queer w Polsce i na Zachodzie, „Przegląd Kulturoznawczy” 2012, część B.

${ }^{15}$ O. Tokarczuk, Kobieta nie istnieje, s. 7.

${ }^{16}$ K. Tomasik, Potencjalna emancypacja, w: Homobiografie. Pisarki i pisarze polscy XIX i XX wieku, Wyd. Krytyki Politycznej, Warszawa 2009, s. 115. 
temu, co pisała de Beauvoir, homoseksualistami się rodzimy, a nie stajemy. Spivak nazywa to zaś strategicznym esencjalizmem.

Mamy dyskurs queerowy, który dąży do zburzenia wszystkich opozycji jako ograniczających, dąży do transgenderyzmu, czyli swobodnego przekraczania ograniczeń płciowych. Dyskurs ten afirmuje indywidualne wybory tożsamości płciowej w oparciu o indywidualne fantazmaty płciowe. Wykazuje on pewne skłonności kampowe, karnawałowe, czego wyrazem jest Pride Parade, co drażni starszych homoseksualistów lepiej wtopionych czy zasymilowanych z heteroseksualnym społeczeństwem. Dyskurs queerowy, w swojej jasnej odsłonie, przyjmuje postać drag, wcielania się mężczyzn (bo najczęściej są to mężczyźni) w role kobiet (drag queen) lub crossdressingu (termin lepszy od dawnego transwestytyzmu), czyli zabawnych przebieranek. W ciemnej odsłonie zaś przyjmuje postać transseksualizmu, gdzie każdy jest przed lub po - przed lub po operacji zmiany płci. Małgorzata Radkiewicz zwraca uwagę, że jeśli crossdressing przypisany jest do komedii, od klasycznej komedii Billy’ego Wildera Pół żartem, pół serio (1959) po popularną w Polsce komedię Stanisława Barei Poszukiwany, poszukiwana (1973), to transseksualizm, traktowany jako zaburzenie osobowości, pojawia się najczęściej w thrillerach, filmach kryminalnych i policyjnych, np. w Milczeniu owiec ${ }^{17}$.

Mamy wreszcie dyskurs LGBT, gdzie szczególny niepokój budzi biseksualność. Czy biseksualiści powinni się ujawniać, dokonywać coming outu? Coming out był wyrazem wielkiej odwagi, szczególnie w latach 80., w czasie naznaczonym przez AIDS. Biseksualiści ukrywają swoje homoseksualne przygody, nie chcą składać jednoznacznych deklaracji, chcą pozostać ambiwalentni. Czy heteroseksualne związki, w których często pozostają, powinny być demaskowane jako alibi? Czy środowisko homoseksualne powinno ich zmuszać do opowiedzenia się, po której są stronie? Pytania te nabierają konkretnego wyrazu w odniesieniu do np. Jerzego Andrzejewskiego czy Jarosława Iwaszkiewicza ${ }^{18}$.

Wszystkie cztery dyskursy są konsekwencją rozpadu wielkich narracji. Miejsce wielkich opowieści nowoczesności zajęły dziś małe opowieści tworzone przez grupy wczesnej dyskryminowane i marginalizowane, czyli lekceważone i uznawane za nieistotne (z czyjego punktu widzenia?). Powstaje zatem pytanie, kto ma dzisiaj prawo wypowiadać się w imieniu tych grup? Kto po odebraniu tym grupom prawa głosu ma prawo podłożyć

${ }^{17}$ M. Radkiewicz, Oblicza kina queer: od crossdressingu do filmów transgenderowych, „Przegląd Kulturoznawczy” 2012, część B, ss. 252-253.

${ }^{18} \mathrm{~K}$. Tomasik, Potencjalna emancypacja. 
swój głos? Joanna Mizielińska wierzy, że przywołane tu dyskursy można jakoś uporządkować, wpisać w jakiś ciąg rozwojowy; budzenie społecznej sympatii dla gejów (lata 70.), ruch wyzwolenia gejów budowany na modelu quasi-etnicznej tożsamości (Queer Nation, lata 80.), afirmacja indywidualnego konstruowania tożsamości (queer, lata 90.) ${ }^{19}$.

Nie podzielam tego przekonania, uważam bowiem, że nowa humanistyka będzie musiała skonfrontować się równocześnie z tymi wszystkimi opowieściami, raz jeszcze przemyśleć pojęcie obiektywności (naukowości) i zaangażowania, nauczyć się żyć w spluralizowanym świecie wielu teorii, a właściwie wielu dyskursów oraz nauczyć się współpracować z różnymi grupami w taki sposób, by prezentować ich punkty widzenia. Przede wszystkim zaś będzie musiała zerwać z ideą jednorodności na rzecz różnicy - kiedyś szukano tego, co jednorodne, dziś - raczej tego, co różne, czy będzie to kultura europejska, czy polska.

\section{Literatura}

Bator J., Feminizm, postmodernizm, psychoanaliza. Filozoficzne dylematy feministek drugiej fali, słowo/obraz terytoria, Gdańsk 2001.

Beauvoir S. de, Druga płeć, t. I: Fakty i mity, tłum. G. Mycielska, Wyd. Literackie, Kraków 1972.

Beauvoir S. de, Druga płeć, t. II: Kształtowanie się kobiety, sytuacja, usprawiedliwienia i ku wyzwoleniu, tłum. M. Leśniewska, Wyd. Literackie, Kraków 1972.

Butler J., Uwikłani w płeć, tłum. K. Krasuska, Wyd. Krytyki Politycznej, Warszawa 2008.

Dziamski G., Sztuka feministyczna: od outsidera do innego, w: idem, Sztuka u progu XXI wieku, Wyd. Fundacji Humaniora, Poznań 2002.

Mead M., Płeć i charakter w trzech społecznościach pierwotnych, PIW, Warszawa 1986.

Mead M., Sex and Temperament in Three Primitive Societies, William Morrow, New York 1935.

Mizielińska J., Idee pogubione w czasie - polityka LGBT vs. teoria queer w Polsce i na Zachodzie, „Przegląd Kulturoznawczy” 2012, część B.

Radkiewicz M., Oblicza kina queer: od crossdressingu do filmów transgenderowych, „Przegląd Kulturoznawczy” 2012, część B.

Spivak G.Ch., Z pieczq̨tkq Kalkuty, tłum. J. Majmurek, w: S. Harasym (red.), Strategie postkolonialne, Wyd. Krytyki Politycznej, Warszawa 2011.

Ślęczka K., Feminizm. Ideologie i koncepcje społeczne współczesnego feminizmu, Książnica, Katowice 1999.

Tokarczuk O., Kobieta nie istnieje, wstęp do J. Butler, Uwikłani w płeć, tłum. K. Krasuska, Wyd. Krytyki Politycznej, Warszawa 2008.

Tomasik K., Potencjalna emancypacja, w: Homobiografie. Pisarki i pisarze polscy XIX i XX wieku, Wyd. Krytyki Politycznej, Warszawa 2009.

${ }^{19}$ J. Mizielińska, Idee pogubione w czasie... 